\title{
Use of remote sensing in control of good agricultural and environmental conditions on agricultural farms
}

\author{
Joanna Pluto-Kossakowska, Katarzyna Osińska-Skotak, \\ Anna Fijałkowska, Jerzy Chmiel
}

Faculty of Geodesy and Cartography

Warsaw University of Technology

pl. Politechniki 1, 00-661 Warsaw, Poland

\begin{abstract}
In the frame of EU common agricultural policy, applicant farmers shall receive subsidies for agricultural production. A producer receiving payments is required to meet the basic requirements for the maintenance of all farmland in good agricultural conditions consistence with environmental protection. Since 2009, applicant farmer is obliged to comply with standards adopted by Poland in the so-called cross-compliance requirements. Member States shall determine at the national level for Good Agricultural and Environmental Conditions (GAEC). Compliance with these standards, to maintain good agricultural practice is controlled selectively in the annual inspection campaigns conducted by the Agency for Restructuring and Modernization of Agriculture (ARMA). One of control method is Control with Remote Sensing (CwRS), method that involves the determination in satellite or aerial images boundaries of areas subject to subsidies. Experience in the use of remote sensing, however, indicate the potential for the use of processed satellite or air orthophotomaps not only for cropping delineation but also to verify certain elements of agricultural practices. During the CwRS routine, one could indicate a possible non-compliance issues directly on the image and thereby optimize the process of control. The studies indicated which of the requirements to maintain land in good agricultural conditions might be monitored with CwRS. The results of the series of experiments showed that both kind of aerial and satellite orthophoto can be consider as equivalent materials. Features or phenomenon spread over a large area or occurred point-wise are detectable in image easier than during field inspection. Also wherever access or visibility on the ground is limited due to the morphology complexity, road network, etc., orthophotomap provide better angle of view. Nevertheless, the ratio benefit/cost for managing the entire control on national level should be checked against the efficiency of field control.
\end{abstract}

Key words: remote sensing, aerial orthophotomap, satellite image, good agricultural and environmental conditions, cross-compliance

\section{Introduction}

Direct payments are the instrument of financial support for farmers in Europe. After the accession to the EU more than 1,4 million Polish farmers have been included into system of supporting farmer's income under the Common Agricultural Policy. As a result Poland introduced the socalled Single Area Payment Scheme (SAPS), which relies on granting financial benefit to a farmer proportionally to the crop area, regardless of agricultural production volume.
In order to receive direct payments, a farmer has to fulfil a set of rules on cross-compliance. As a paying agency, ARMA is responsible for controls if these rules are observed by farmers and for imposing sanctions in case of infringement. These rules include keeping land in good agricultural and environmental conditions (GAEC) which concern the issues of soil erosion, soil organic matter, soil structure, minimum level of maintenance, protection and management of water and maintaining the total area of permanent pasture and observing Statutory Management 
Requirements (SMR) which cover rules relating to agricultural productions, lands and activities in the three areas of the environment (the public, animal and plant health) and the animal welfare as well.

In order to manage the direct payments an Integrated Administration and Control System (IACS) was set up. It refers to the identification of farmers, identification and registration of payments entitlements, control system as regards cross-compliance. ARMA is responsible for keeping and updating the Land Parcel Identification System (LPIS), which is established on the basis of maps, land registry documents and other spatial data including aerial or satellite imageries. All these data are incorporated into a Geographical Information System (GIS), which also contains the boundaries of the reference parcels and their eligible area (arimr.gov.pl).

Cross-compliance is not an eligibility condition for payments but triggers reductions when not respected. The reductions must take account of the severity, extent, permanence and repetition of the non-compliance found. Reductions leads to decrease of the overall aid amount granted to farmer for the year when the finding was made. The percentage of reduction for non-compliance that shall be applied depends if the non-compliance is due to negligence or intentionality (WikiCAP).

The requirements of cross compliance on farm management are not new rules, decreed for the reform of the Common Agricultural Policy (CAP), as the fulfilment of assumed obligations of this policy, have already been implemented in national legislation. Following these rules is now mandatory for all farms. A new element is the only link between the granting of direct payments complying with these regulations.

Member States are required to carry out checks on cross-compliance to verify whether the farmer complies with the requirements and standards under cross-compliance. At least $1 \%$ of all farmers submitting aid application for direct payments is controlled with on-the-spot (OTS) checks. The selection of the sample of farms to be controlled is based on a risk analysis using LPIS.

Two main approaches are present in OTS check procedures: field inspection as conventional one or Control with Remote Sensing (CwRS). The choice of control method including modifications, variants, tools is a decision of the Member State, usually as result of different experiences and preferences concerning certain technology.

On-the-spot checks cover at least (EC 2011a):

- the declared area of the agricultural parcel;

- the compliance with the minimum area of the agricultural parcel where necessary;

- the declared land use to the extent requested by the regulation (i.e. crop group);

- the number and/or position of trees where necessary;
- the eligibility of the parcel with respect to the reference period where applicable;

- the respect of cross compliance requirements and particularly of GAECs.

The Control with Remote Sensing lies in visual photo-interpretation of agricultural parcels on Very High Resolution (VHR) aerial or satellite orthophotomap of the current year. The area of agricultural parcels, their land use (crop) if requested by the national administration and cross compliance issues are checked. In the case where the diagnosis may not be completed by computer-aided photo-interpretation (CAPI) procedures alone, Rapid Field Visits (RFV) is carried out (EC 2011a). In Poland this procedure is called PHOTO method with RFV and can be seen to some extent as a simplified variant of the CwRS. It is considered as a method allowing to check the land use and possibly some cross compliance issues (GAECs) in the field without contacting the farmer. In recent years, the percentage of total number of checks carried out with the PHOTO method was at the level above 20 percent (2008) and it continuously increases.

As a general assumption of the PHOTO method, the necessary parcel area measurements to check the declared area are done directly on Very High Resolution (VHR) satellite orthoimage in the office work. In case where some parcel features are not clearly identifiable on the VHR orthoimagery some measurement is taken later during RFV. The other elements of checking like declared land use or crop group can be checked directly during the field control as well. The digital photographs of the parcels are taken during this inspection and stored in a database with their location, thus reducing the number of follow up field inspections to a minimum (WikiCAP).

The controls done by PHOTO method already in the first years of its application showed effectiveness and great opportunities for the use of remote sensing, which could lead to a reduction in the range and the number of necessary controls in the field (Pyka \& Świerczek 2005; Wężyk et al. 2009).

The possibilities and achievements in using of remote sensing seems to indicate the potential use in broader range (an optimal variant of PHOTO method) the appropriately processed satellite images together with the relevant GIS analyses in control procedure described above. This should increase the number of elements to be controlled without the inspection in the field.

OTS checks cover all the agricultural land of the holdings. Nevertheless, the actual inspection in the field may be limited to a sample of at least half of the parcels concerned by the requirement or standard. Member States may make use of remote sensing technology to perform or assist the on-the-spot-checks. Poland is one of the few countries where GAEC control is carried out practically based on inspections in the field using RS technology supportive- 
Table 1. GAEC framework according to Council Regulation, 73/2009

\begin{tabular}{|c|c|c|}
\hline Issue & Compulsory Standards & Optional Standards \\
\hline \multirow{2}{*}{$\begin{array}{l}\text { Soil erosion: Protect soil through appropriate } \\
\text { measures }\end{array}$} & Minimum soil cover & \multirow[b]{2}{*}{ Retain terraces } \\
\hline & $\begin{array}{l}\text { Minimum land management reflecting site-specific } \\
\text { conditions }\end{array}$ & \\
\hline $\begin{array}{l}\text { Soil organic matter: Maintain soil organic } \\
\text { matter levels through appropriate practices }\end{array}$ & Arable stubble management & Standards for crop rotations \\
\hline $\begin{array}{l}\text { Soil structure: Maintain soil structure through } \\
\text { appropriate measures }\end{array}$ & & Appropriate machinery use \\
\hline \multirow{4}{*}{$\begin{array}{l}\text { Minimum level of maintenance: Ensure } \\
\text { a minimum level of maintenance and avoid } \\
\text { the deterioration of habitats }\end{array}$} & $\begin{array}{l}\text { Retention of landscape features, including, where } \\
\text { appropriate, hedges, ponds, ditches, trees in line, in } \\
\text { group or isolated and field margins }\end{array}$ & $\begin{array}{l}\text { Minimum livestock stocking } \\
\text { rates or/and appropriate } \\
\text { regimes }\end{array}$ \\
\hline & $\begin{array}{l}\text { Avoiding the encroachment of unwanted vegetation } \\
\text { on agricultural land }\end{array}$ & $\begin{array}{l}\text { Establishment and/or } \\
\text { retention of habitats }\end{array}$ \\
\hline & Protection of permanent pasture & $\begin{array}{l}\text { Prohibition of the grubbing } \\
\text { up of olive trees }\end{array}$ \\
\hline & & $\begin{array}{l}\text { Maintenance of olive groves } \\
\text { and vines in good vegetative } \\
\text { condition }\end{array}$ \\
\hline \multirow[b]{2}{*}{$\begin{array}{l}\text { Protection and management of water: Protect } \\
\text { water against pollution and run-off, and } \\
\text { manage the use of water }\end{array}$} & Establishment of buffer strips along water courses & \\
\hline & $\begin{array}{l}\text { Where use of water for irrigation is subject to } \\
\text { authorisation, compliance with authorisation } \\
\text { procedures }\end{array}$ & \\
\hline
\end{tabular}

Each standard has own requirements and parameters. They are briefly described below

ly only. The examples where RS is used extensively for control are coming from Austria, Czech Republic, France, Hungary and Italy (GAEC workshop 2011). The results of study conducted by AGEA-SIN (Italy) have demonstrated advantage of control with remote sensing over inspections in the field. On the test area, the recognition of violations by CAPI reached 32-33\% level of detection, while by field inspectors $26 \%$.

\section{GAEC framework}

Minimum GAECs requirements should be defined for all compulsory standards and they should take into account the specific characteristics of the areas concerned, including soil and climatic condition, existing farming systems, land use, crop rotation, farming practices and farm structures. They are defined at national level on the basis of 5 issues and 15 standards (8 compulsory and 7 optional) shown in Tab. 1.

\section{Issue: soil erosion}

Standard: Minimum cover and retain terraces. In the case of perennial plants plantations located on slopes with a gradient exceeding 20 degrees, it is compulsory to retain the plant cover or to mulch in inter-rows or to cultivate on the basis of terraces.

Standard: Minimum land management reflecting site specific conditions. Arable land situated on slopes with a gradient greater 20 degrees should not be used for cultivation of plants that require furrowing or ridging along the slope or maintained as a bare fallow.

\section{Issue: soil organic matter}

Standard: Crop rotation where applicable. As far as cereals are concerned, a maximum 3-year-long period of cultivation on the same plot is to be introduced.

Standard: Arable stubble management. Burning out of agricultural land, including post-harvest (a combine harvested) remains, is forbidden. Meadows, pastures and stubbles should not be cleared by burning neither. 


\section{Issue: soil structure}

Standard: Appropriate machinery use. It is forbidden to carry out cultivation treatment by means of heavy equipment for agriculture in the period of soil profile water saturation.

\section{Issue: Minimum level of maintenance}

Standard: Minimum livestock stocking rates or appropriate regimes. In the case of pastures, grazing animals in the grasses vegetation period or mowing of plant cover and its removal at least once a year, by 31 July is required.

Standard: Protection of permanent pasture. Meadows and pastures should not be changed into arable land. Standard: Retention of landscape features. Agricultural land should not be planted with trees or shrubs, with the exception of:

a) trees and shrubs which are not cut in line with regulations for nature protection, have no impact on plant production carried out on this land or have importance for water and soil protection;

b) willow (purple)-only for plaiting.

Standard: Avoiding the encroachment of unwanted vegetation on agricultural land. In the case of fallow land, at least once a year, by 31 July, mowing and other operations preventing the appearance and spread of weeds are required. Arable land, on which crops are grown, or which is fallow land, or is situated on slopes, should not be overgrown by trees and bushes, with some exceptions. In the case of meadows and/or pastures, grazing animals in the grasses vegetation period or mowing of plant cover and its removal at least once a year by 31 July. In the case of short rotation coppices used as energy crops with the exception to willow (Salix sp.) for plaiting and wearing are acknowledged as cultivated according to standards, if: they are kept in a weed less state, harvest takes place on the basis of a maximum four year long cycle for fibre or eight year long cycle for wood, are situated $1.5 \mathrm{~m}$ from the neighbouring plot, on which such a plantation has been established or is used as a forest, or $3 \mathrm{~m}$ from the neighbouring plot used for other purposes than the plantation of short rotation coppices or as a forest land (Angileri 2008).

The additional conditions which must be fulfil by farmers who joined the special agri-environmental scheme, were not considered under this study.

\section{Materials and Methods}

As a method of research, the systematic analysis of the requirements and standards according to mentioned documents was used. Although all standards were examined, only some of them have been selected to show capacity of remote sensing and photo-interpretation techniques.

The data used for this research are two sets of orthophotomaps. One of these was derived from aerial images acquired in three different phenological periods June 2010, September 2010 and April 2011 for the area of central Poland (Mazovia Region) and one of southern Poland (Pomerania). These orthophotomaps are generated with $0.25 \mathrm{~m}$ and $0.50 \mathrm{~m}$ resolution in two colour compositions: RGB using visual bands and CIR with infrared band. The same data are used for LPIS (Land Parcels Identification System) creation by ARMA.

The second orthophotomap was created from multispectral satellite image WorldView acquired on 4.08.2011 covered suburban of Warsaw (central Poland). This kind of data are used during control campaign for CwRS method. Additional this satellite image panchromatic and multispectral mode ( 8 bands) were transformed together in fusion process ${ }^{3}$ reaching spatial resolution of $0.50 \mathrm{~m}$. Different colour compositions with optical $(1,2,3,4,5,6)$ and infrared $(7,8)$ bands were created and tested. Pseudo-natural composition RGB 531 and infrared composition RGB 752 were chosen as the most useful in agricultural parcels interpretation.

The diversity of source data supplied research material showing disparate type of the landscape (flat or moderate) and covering different seasons from Spring till Autumn. Therefore it was possible to find various agrarian activities and treatments in relation to vegetation phases and to topography performed on the field.

Based on above described requirements and previous experiences the shortlisted RS use is produced. The list of all infringements checked by OTS is shown in Tab. 2.

Almost for all requirements use of RS data is applicable, except the case when authorised documents during the control are required (i.e. water law permit), however the irrigation itself is detectable on image. Few of them such as crop rotation, permanent pasture change of use or natural habitats preservation, need archival data to be properly verified. There is also group of conditions depending on time like mowing, tillage or grazing, require exact date of the image (e.g. 31 July) or winter images to check ground cover during particular period 1 December till 15 February. Another group of phenomenon might be detected but limited to their occurrence e.g. burning or water saturation of the soil profile. Some of the clear examples are shown in next paragraph. For the part of requirements not only images but also Digital Elevation Model (DEM) is needed. This group of good practices refer to crops located on slopes. Although the requirements consider the slope gradient exceeding 20 degrees, the effect of erosion it is clearly

\footnotetext{
${ }^{3}$ Using Principal Component Analysis
} 
Table 2. RS data use for infringement control: ++ high, + limited, - inability

\begin{tabular}{|c|c|c|c|}
\hline No & Infringement & $\begin{array}{l}\text { Remote } \\
\text { Sensing data } \\
\text { use }\end{array}$ & Comments \\
\hline 1 & $\begin{array}{c}\text { Arable land is not used for growing crops } \\
\text { or fallow land }\end{array}$ & ++ & \\
\hline 2 & $\begin{array}{l}\text { grown in the same area the same plant species: wheat, oats, rye or barley } \\
\text { for more than } 3 \text { years or before this plant growing in a } 4 \text { or } 5 \text { years did not } \\
\text { perform certain actions. }\end{array}$ & + & $\begin{array}{l}\text { Archival data required, } \\
\text { GIS }\end{array}$ \\
\hline 3 & not carry out the set-aside land mowing or tillage in time by 31 July & + & $\begin{array}{l}\text { Multitemporal data } \\
\text { or exact date }\end{array}$ \\
\hline 4 & $\begin{array}{l}\text { not carry out in the meadows and pastures needed mowing and removal of } \\
\text { ground cover at a time or they were not grazing animals. }\end{array}$ & + & $\begin{array}{l}\text { Multitemporal data } \\
\text { or exact date }\end{array}$ \\
\hline 5 & $\begin{array}{c}\text { not maintain ground cover during the period from } 1 \text { December to } 15 \text { February } \\
\text { at least } 40 \% \text { of arable land comprising the farm. }\end{array}$ & + & $\begin{array}{l}\text { Winter images required, } \\
\text { Snow cover }\end{array}$ \\
\hline 6 & $\begin{array}{l}\text { traces of burning on agricultural land, with the exception of spot traces of } \\
\text { crop residues. }\end{array}$ & + & $\begin{array}{l}\text { phenomenon occurrence } \\
\text { depended }\end{array}$ \\
\hline 7 & $\begin{array}{l}\text { on agricultural land tillage performed heavy equipment during water } \\
\text { saturation of the soil profile. }\end{array}$ & + & $\begin{array}{l}\text { phenomenon occurrence } \\
\text { depended }\end{array}$ \\
\hline 8 & $\begin{array}{l}\text { within the parcel trees being monuments of nature, ditches up to } 2 \text { meters } \\
\text { wide or ponds to } 100 \mathrm{~m}^{2} \text { were destroyed }\end{array}$ & + & $\begin{array}{l}\text { Archival data required } \\
\text { GIS }\end{array}$ \\
\hline 9 & $\begin{array}{c}\text { plant and animal habitats of protected species or natural habitats have been } \\
\text { destroyed. }\end{array}$ & + & GIS \\
\hline \multirow{4}{*}{10} & plantations of short rotation coppices are weed. & - & \\
\hline & Perennial plantations are weed. & - & \\
\hline & $\begin{array}{l}\text { failure to comply with the minimum distance from the border of } \\
\text { a neighbouring plot of land on which it was founded the same plantation with } \\
\text { short rotation coppices, or parcel utilized as forest land. }\end{array}$ & + & GIS \\
\hline & $\begin{array}{l}\text { failure to comply with the minimum distance between short rotation coppice } \\
\text { and neighbouring parcels, which are used as agricultural land. }\end{array}$ & + & GIS \\
\hline \multirow{2}{*}{11} & $\begin{array}{c}\text { arable land located on slopes over } 20^{\circ} \text { are used for growing plants that require } \\
\text { the maintenance of ridges along the slope }\end{array}$ & ++ & DEM, GIS \\
\hline & arable land located on slopes over $20^{\circ}$ are kept as black fallow & ++ & DEM, GIS \\
\hline 12 & $\begin{array}{l}\text { To retain the plant cover or to mulch in inter-rows in case of perennial plants } \\
\text { plantations located on slopes with gradient exceeding } 20^{\circ}\end{array}$ & + & DEM, GIS \\
\hline 13 & $\begin{array}{c}\text { change in the use of permanent pasture, or parts thereof without the required } \\
\text { approval }\end{array}$ & + & Archival data required \\
\hline 14 & irrigation of land without a water law permit & - & \\
\hline 15 & Not maintaining buffer zones along water courses & + & GIS \\
\hline
\end{tabular}


visible even in less decline. There is also the group which may be controlled using LPIS, such as buffer zones along water courses or minimum distance between coppices to neighbouring parcels.

The further detailed investigation of using both resources: aerial and satellite data was conducted for chosen requirements, at least one for each GAECs' issue.

\section{Results and Discussion}

The research material obtained by photo-interpretation was analysed and the most typical examples concerning particular requirements are shown below.

\section{Issue: soil erosion}

According to two standards: minimum cover or retain terraces, for perennial plants located on slopes exceeding $20^{\circ}$, it is compulsory to retain the plant cover or to mulch in inter-rows or to cultivate on the basis of terraces. In figure 1 can be seen the direction of growing and mowing which indicate gradient of the slope. In the absence of images of areas on slopes exceeding $20^{\circ}$, the condition regarding the direction of growth of vegetation or maintenance of plant and litter in inter-rows was checked on the available materials. It was assumed that regardless the terrain, the techniques of image interpretation are comparable and the experience can be easily move to area with significant slopes. This approach is supported also by the fact of finding the area affected by erosion, which slope determined from DEM does not exceed $1.5^{\circ}$.

According to standard: Minimum land management reflecting site specific conditions, arable land situated on slopes with a gradient greater than $20^{\circ}$ should not be used for cultivation of plants that require furrowing or ridging along the slope or maintained as a bare fallow. In figure 2 there is a good example of planting across the fall line. Where runoff occurs on unstable soils (such as on light sandy and silty soils), water erodes and transports soil particles. This may be seen as shallow channels (rills) and sometimes more deeper gullies. In figure 3 there are these typical marks on ploughed area. The terrain is rather moderate with slopes of $1.5^{\circ}$ (calculated based on DTED2 and topographic map 1:10 000 independently), falling into class 1 of erosion hazard ${ }^{4}$.

\section{Issue: Minimum level of maintenance}

According to standard: avoiding the encroachment of unwanted vegetation on agricultural land, land is considered as being used for agricultural production when: a crop has been planted; preparatory work for a following crop has commenced; animals are grazing; land is used for growing of grass to be cut or to be grazed. In Figure 4 the centre of parcel is not used for growing crops nor fallow. In figure 5 in infrared composition can be seen red places with vegetation with a few scattered bushes on it. The rest of the parcel looks neglected and unattended.

\section{Issue: Soil organic matter}

According to the standard: Arable stubble management, burning out of agricultural land, including post-harvest remains, it is not allowed. Meadows, pastures and stubbles should not be cleared by burning neither. Traces of burning if it occurred can be recognized on both infrared and visible images. Smoke, shadow of smoke and even flame (yellowish-orange spot) is recognized in orthophoto easily (Fig. 8). In figure 6 fresh, deep brown and black marks of burning in the orchards. In figure 7 there are traces of burning on arable land: on the right parcel - the newer and fresher. On the left parcel, there are older - lighter, reddish shade with the vegetation starting up again. Visible white smoke unambiguously indicates the course and direction of the burn. The dark brown shade shows freshly burned area.

\section{Issue: soil structure}

According to the standard of using appropriate machinery, it is recommended to refrain from field work if water is standing on the surface or the soil is saturated. Saturation is indicated on the image by the appearance of darker shade of soil. Heavy machines leave visible, dark signs on the ground. In figure 9 the plot on the left indicates a significant waterlogged and field work carried out in orchard on the right. In figure 10 clearly visible tracks of heavy machineries on arable parcels. In figure 11 can be seen good example of cutting grass with omitting waterlogged ground.

Monitoring of other standards like: crop rotation, retention of landscape features (ditches, ponds) or change of permanent pastures, the archival data (orthophotomap or LPIS data) are needed. To check: trees being monuments or irrigation with licence, the access to another administration registers is required. The buffer zones along water courses, minimum distance between crops on adjacent parcels can be control with vector data from updated LPIS. Nevertheless in these cases current orthophotomaps can be use as auxiliary materials. Further image processing (e.g. spectral, multitemporal or statistical analysis) is recommended to landscape features extraction and to change detection.

\footnotetext{
${ }^{4}$ scale $0-5$ according to Institute of Soil Science and Plant Cultivation (IUNG)
} 


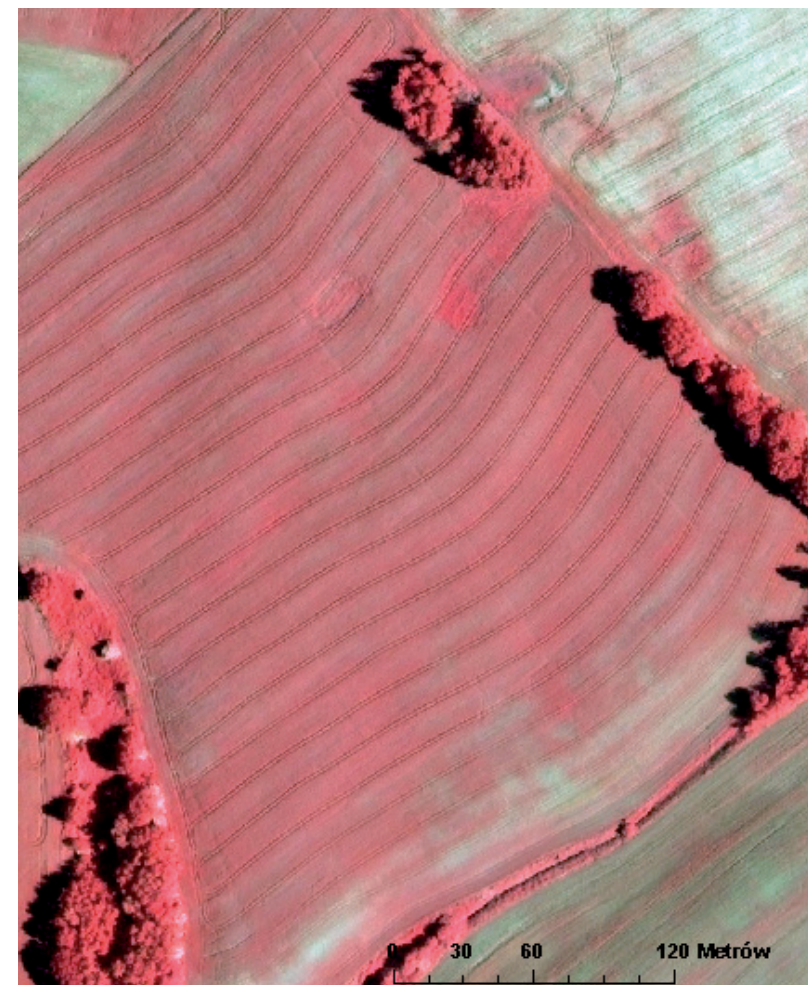

CIR

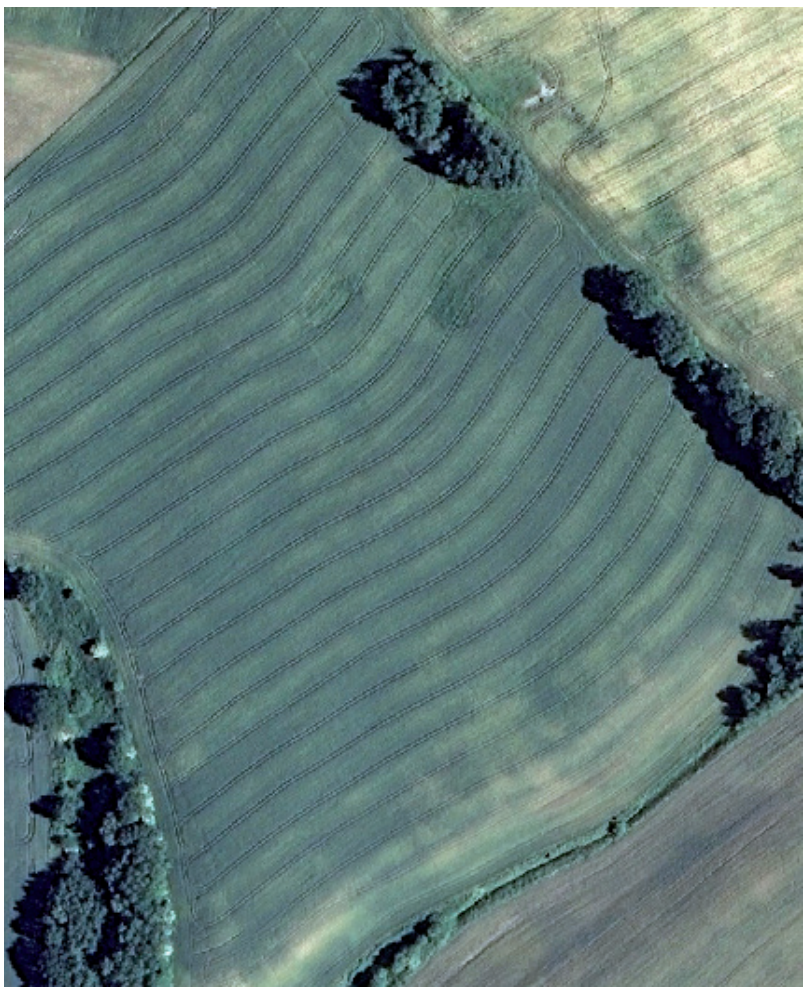

RGB

Figure 1. Orthophoto for Starogard district, June 2010. Good example of growing direction which is perpendicular to the gradient of the slope.

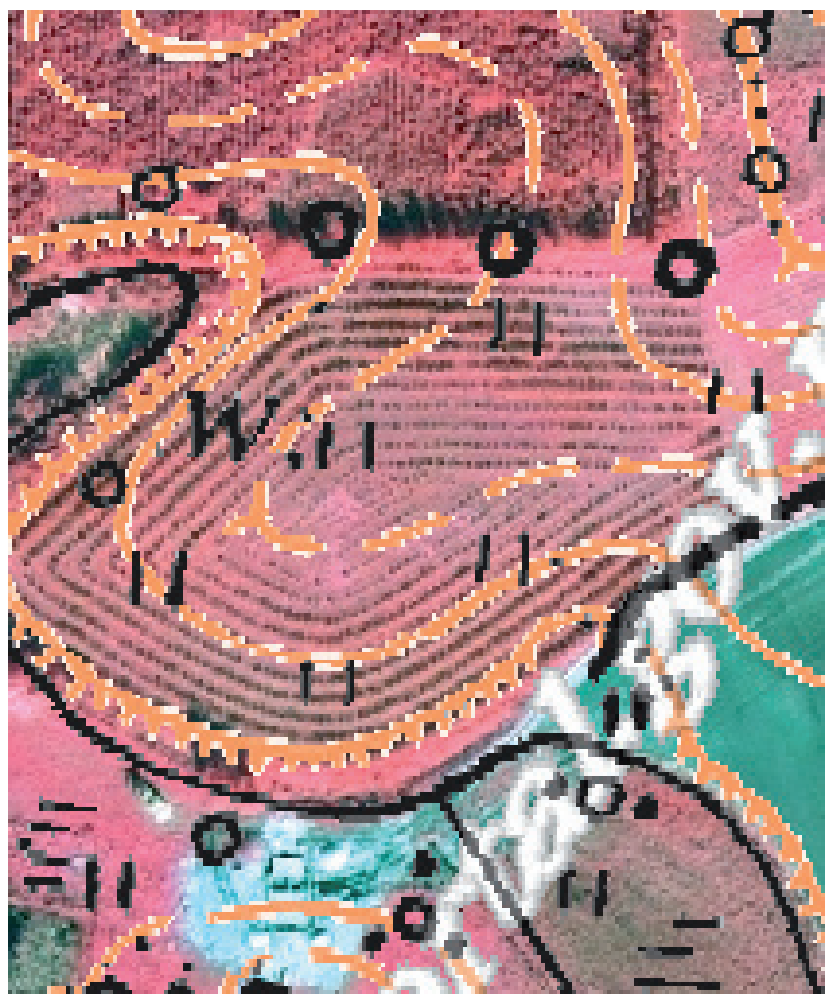

CIR

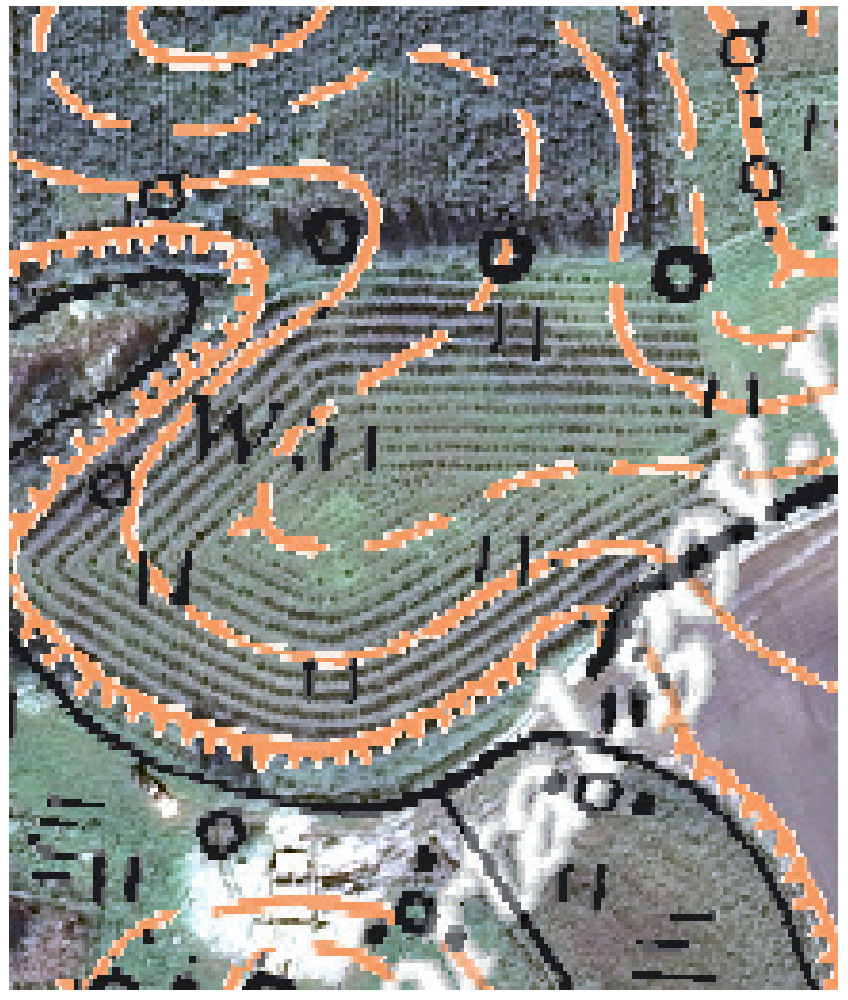

RGB

Figure 2. Orthophotomap for Tczew district, September 2010. Images overlaid with the contour lines of topographic map in scale 1:10 000 (geoportal.gov.pl) 


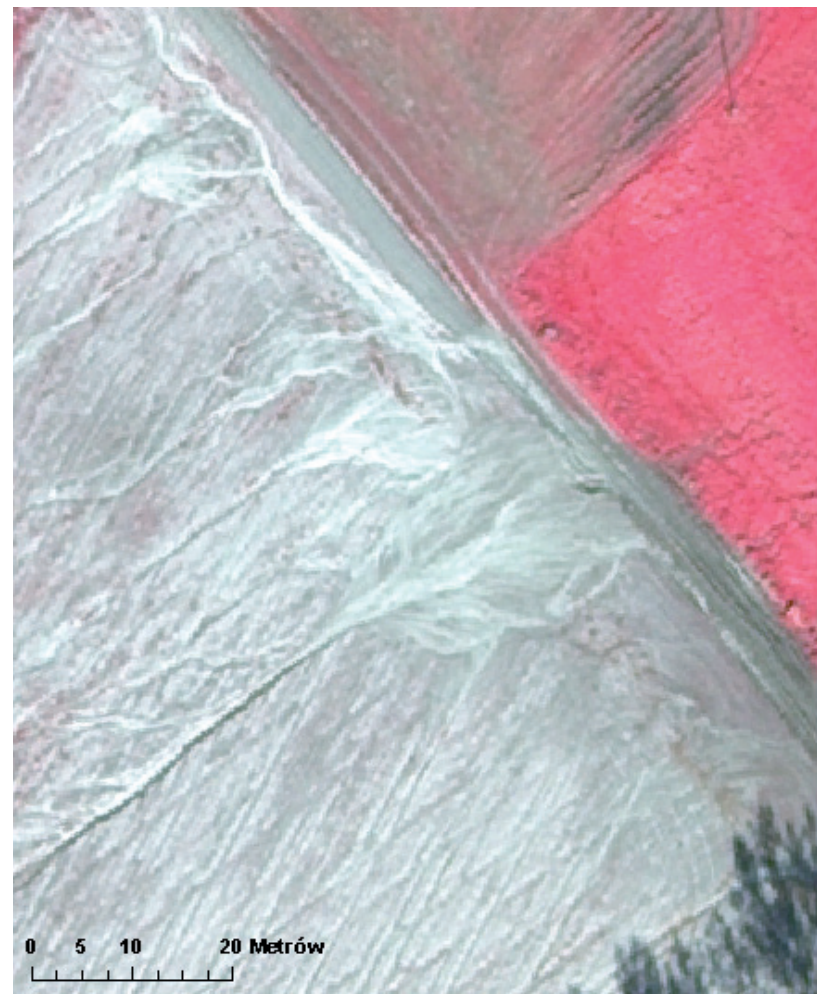

CIR

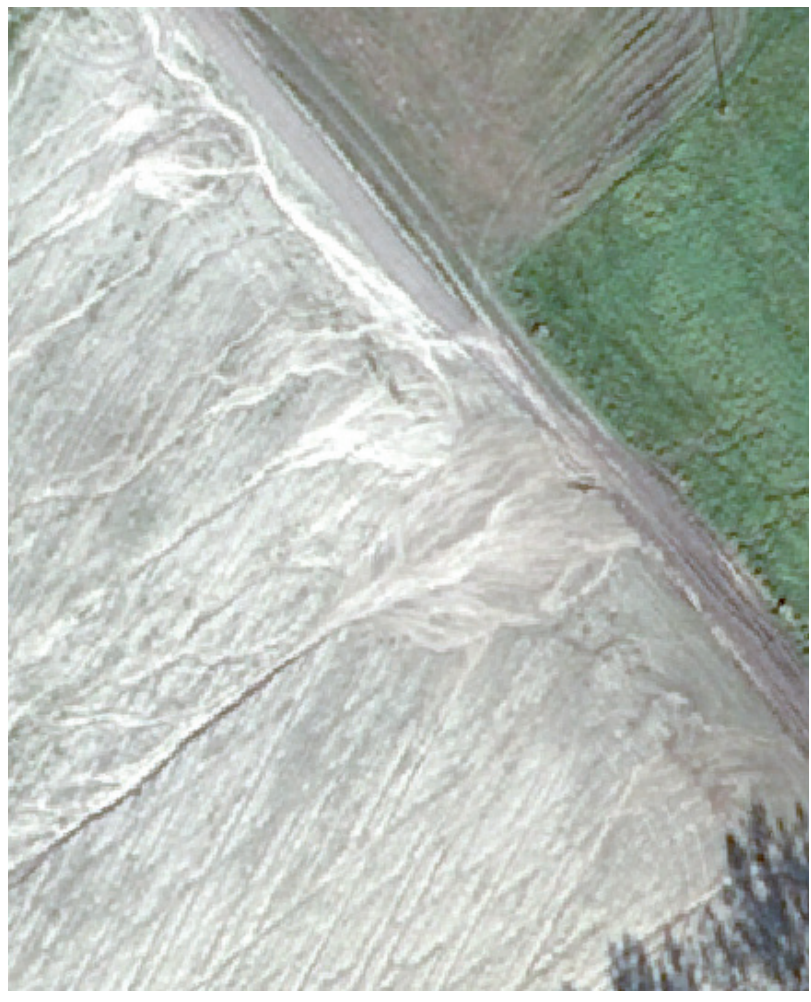

RGB

Figure 3. Orthophoto for Węgrowski district, October 2010. Rills and gullies on the plough area

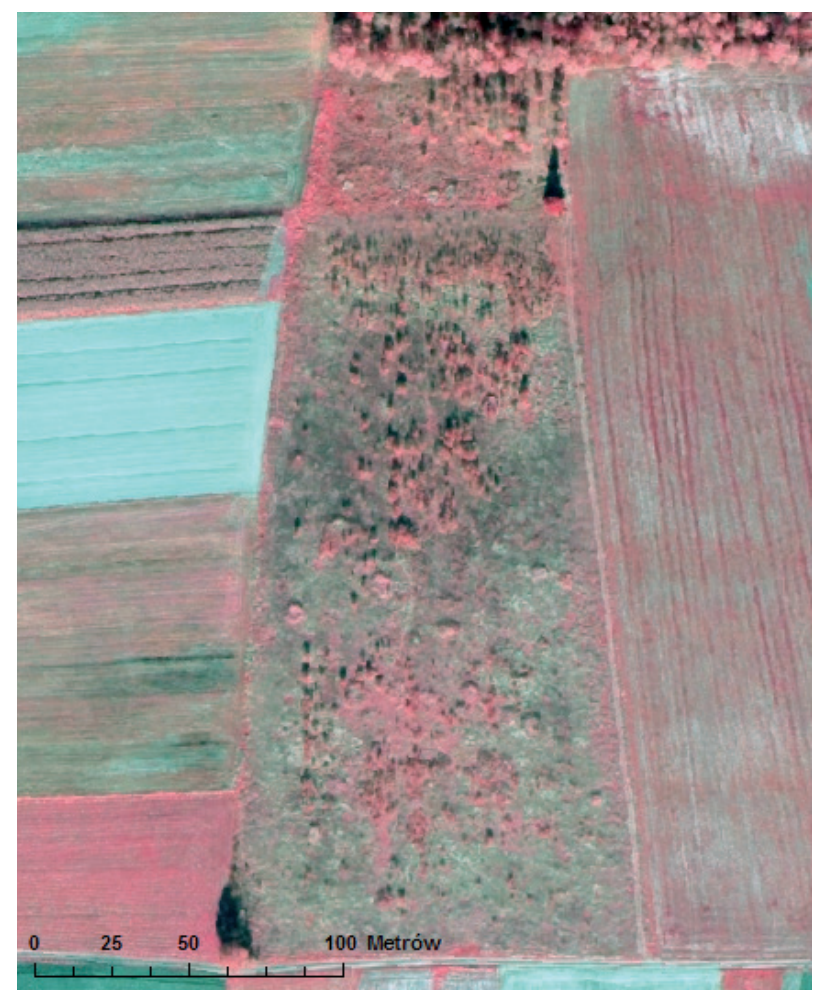

CIR

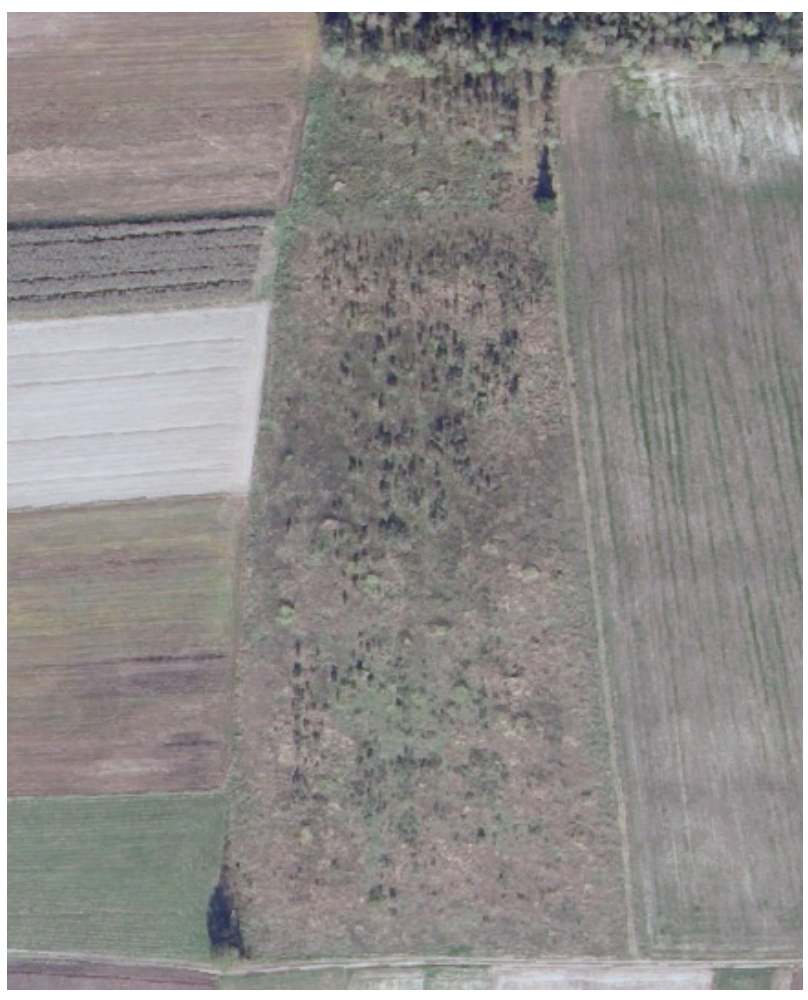

RGB

Figure 4. Orthophoto for Sokołowski district, October 2010, the encroachment of unwanted vegetation 


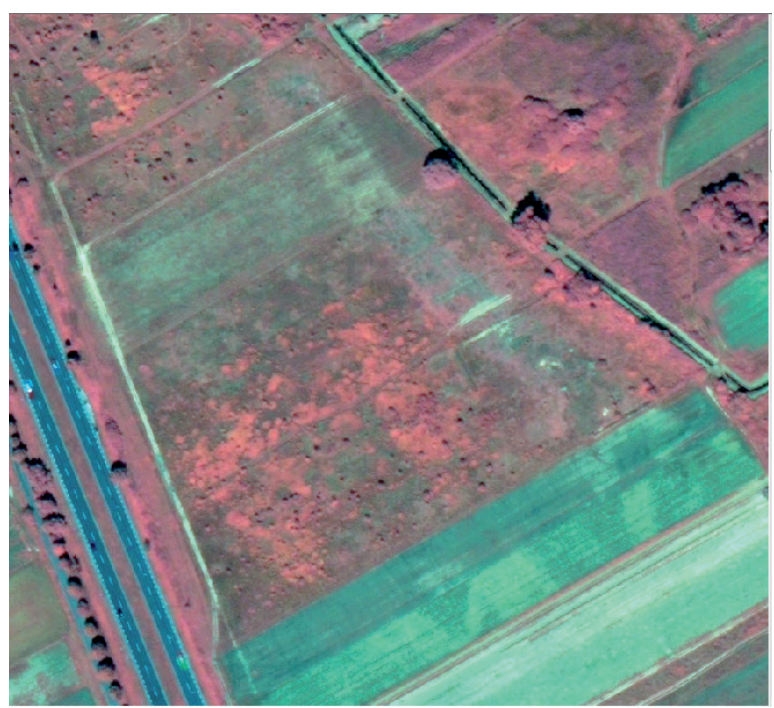

Infrared composition

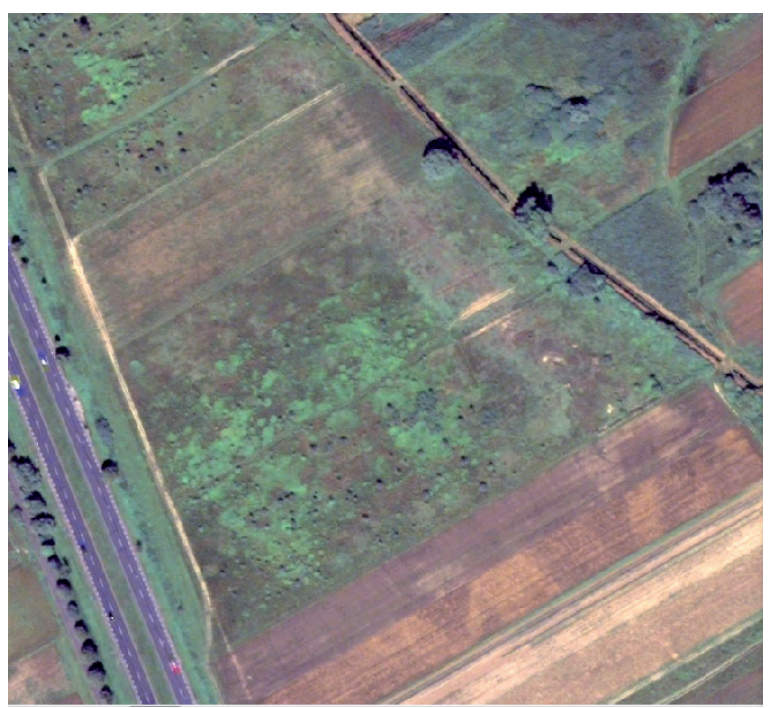

Pseudo-natural composition

Figure 5. Satellite orthophotomap for Powsin district, August 2011, the encroachment of unwanted vegetation on unattended parcel

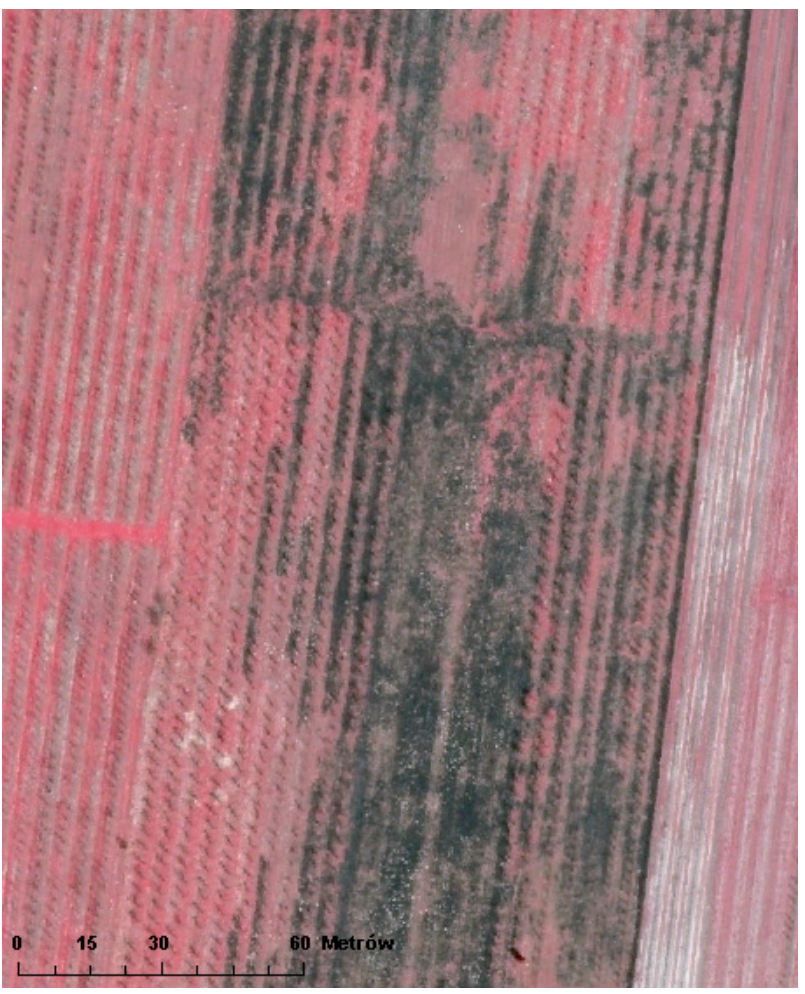

CIR

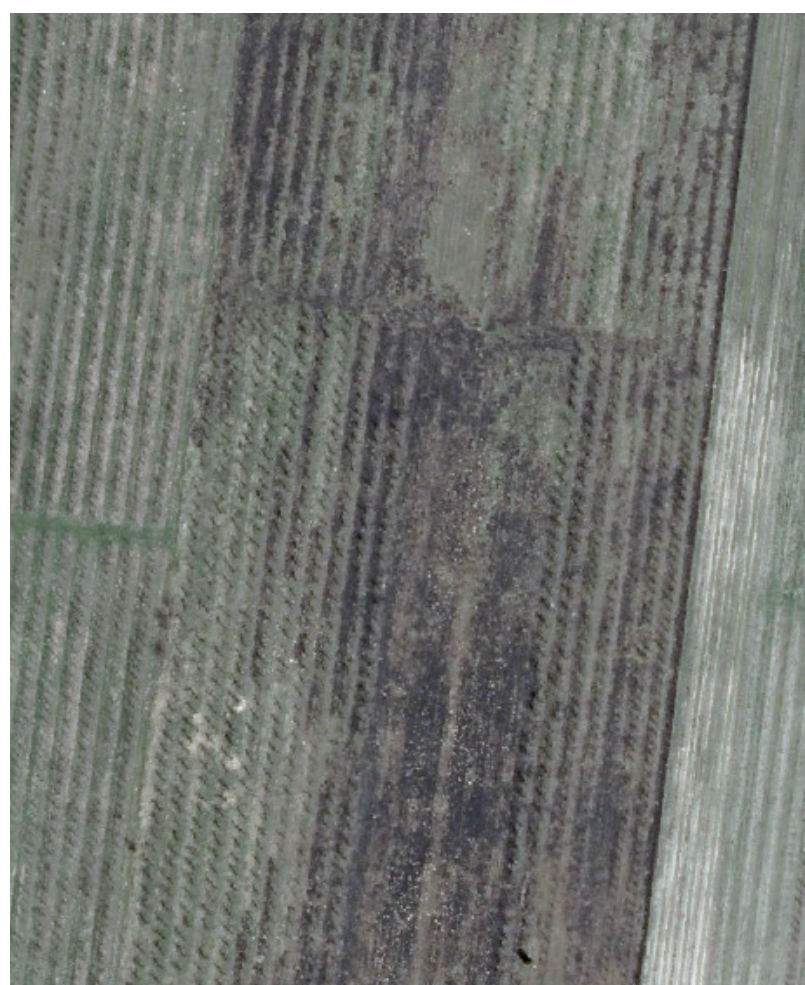

RGB

Figure 6. Orthophoto for Rawski district, April 2011, patches of burnings inside of orchards 


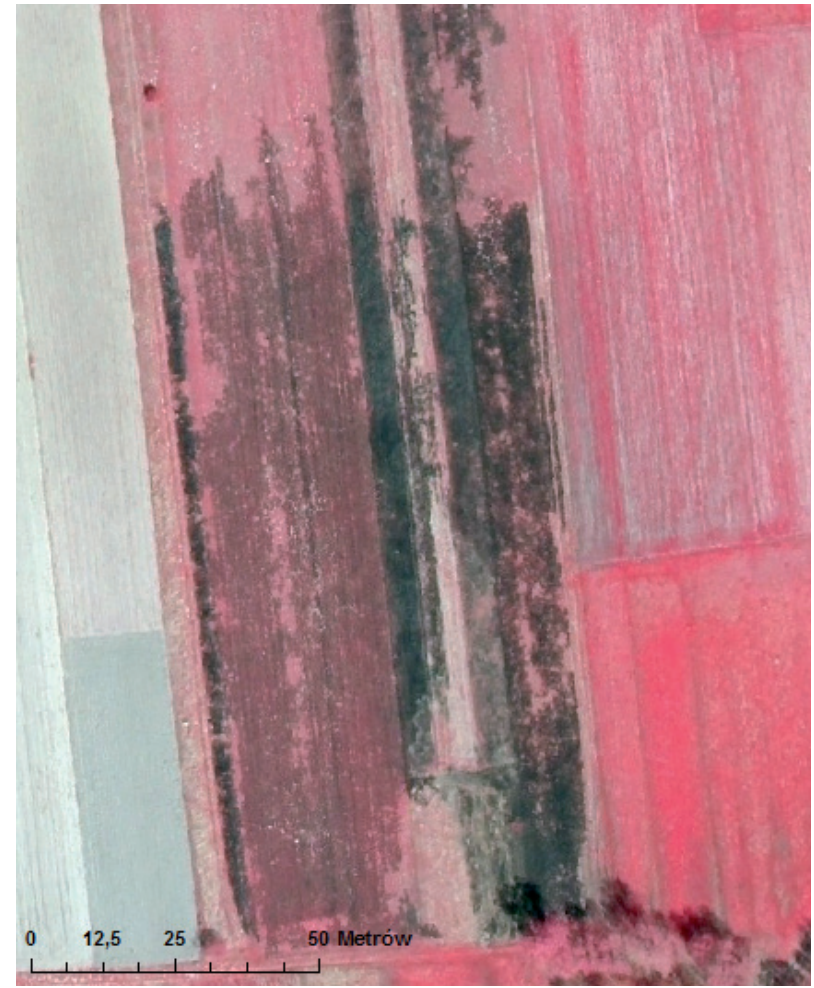

CIR

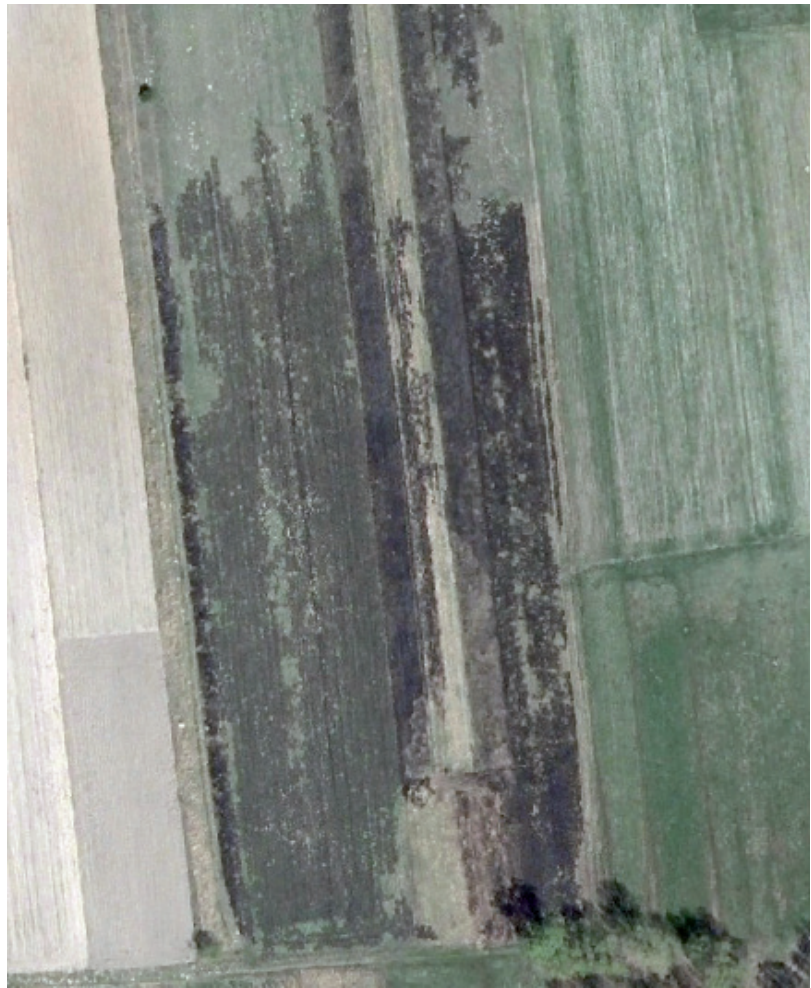

RGB

Figure 7. Orthophoto for Przysuchy district (04.2011), older patches of stubble burnings

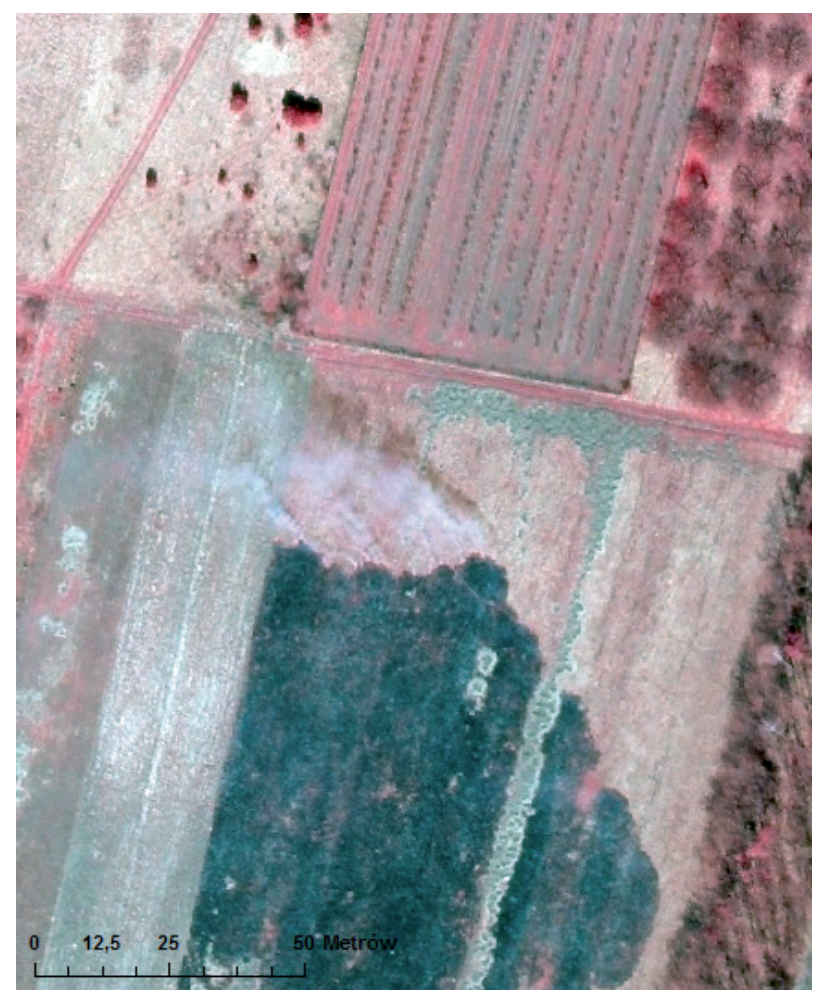

CIR

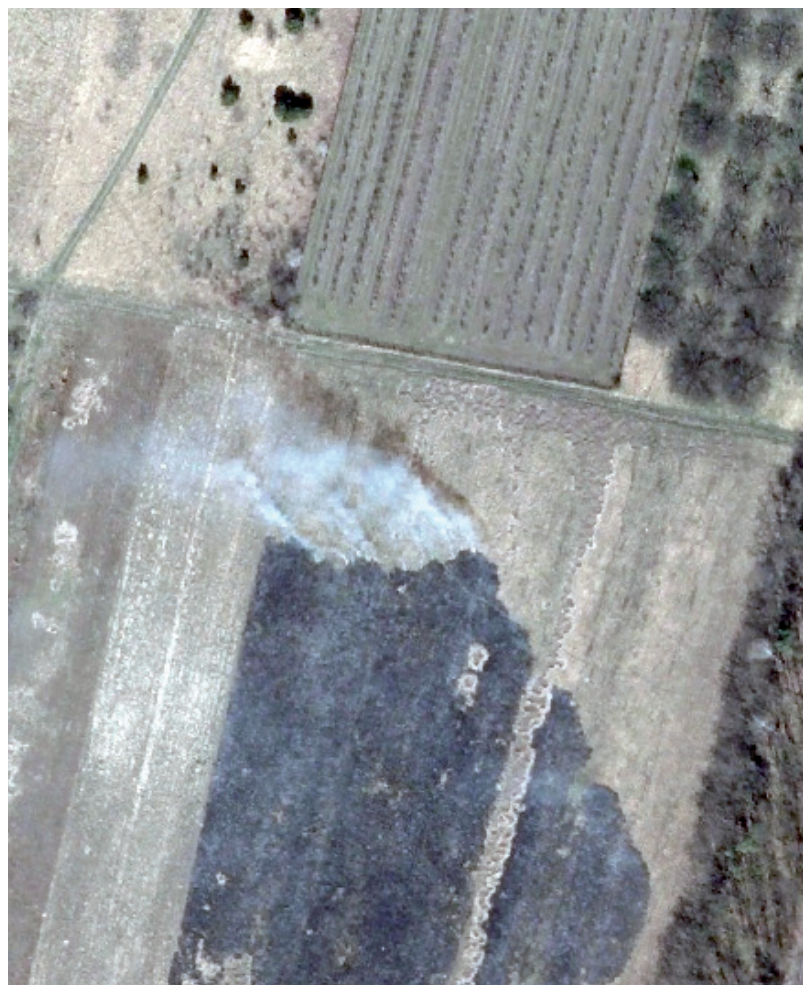

RGB

Figure 8. Orthophoto for Grójecki district, April 2011, ongoing stubble burnings 


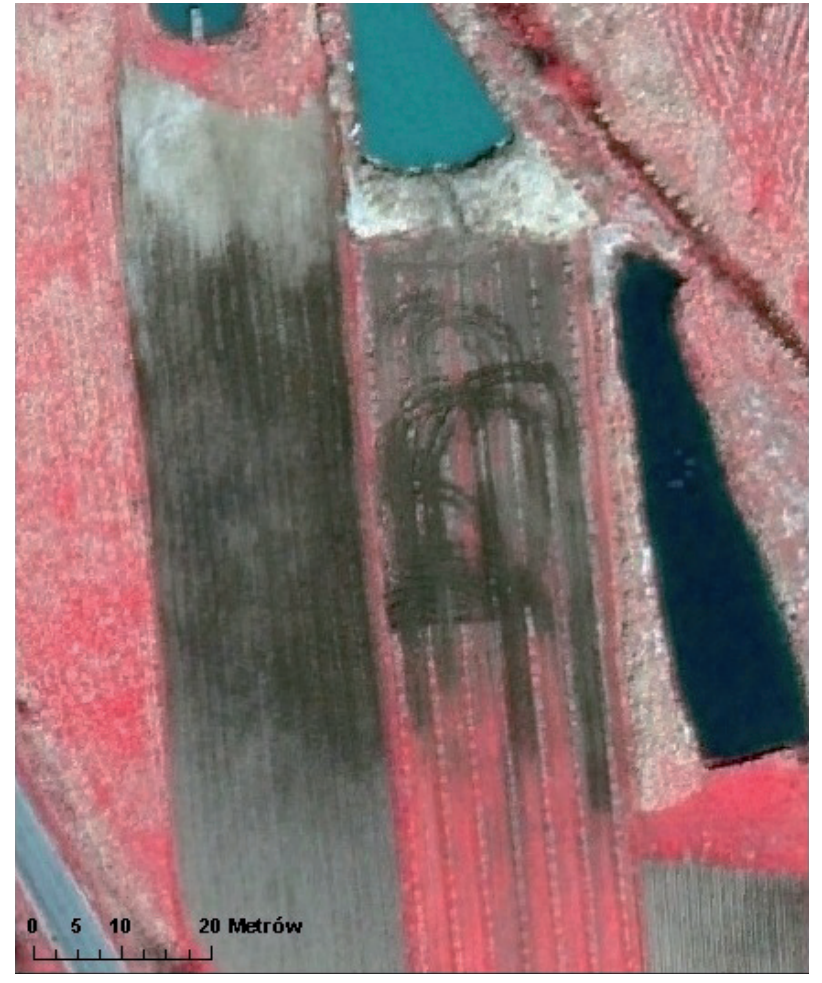

CIR

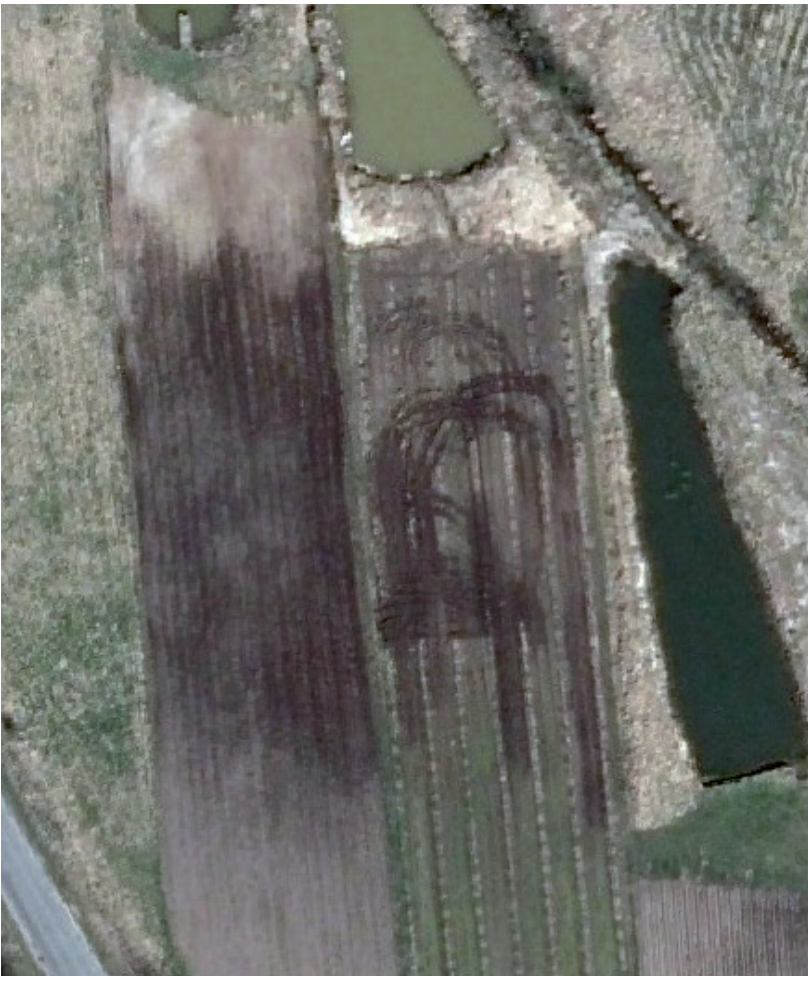

RGB

Figure 9. Orthophoto for Rawa district, April 2011, The plot on the left indicates a significant waterlogged

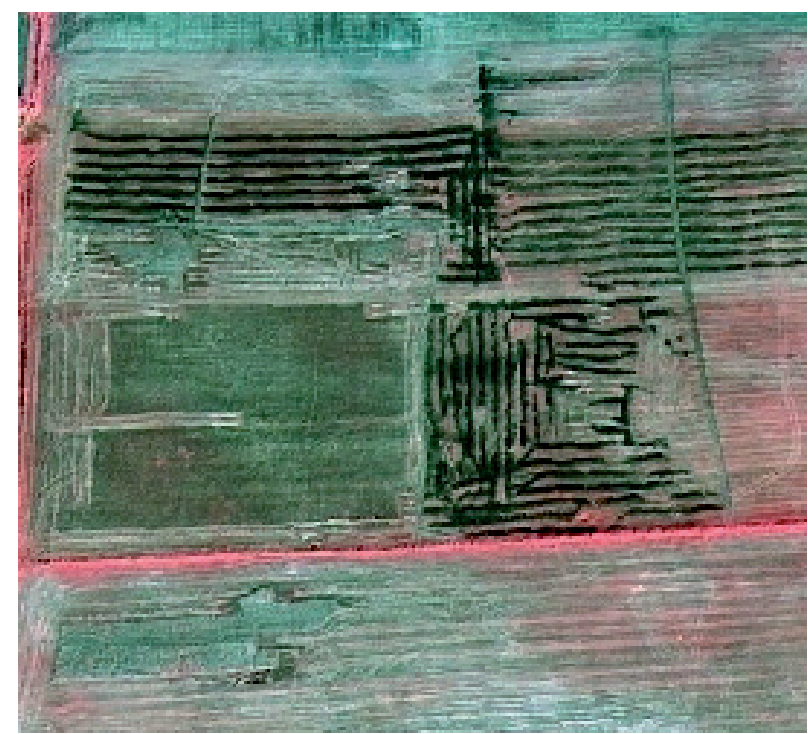

CIR

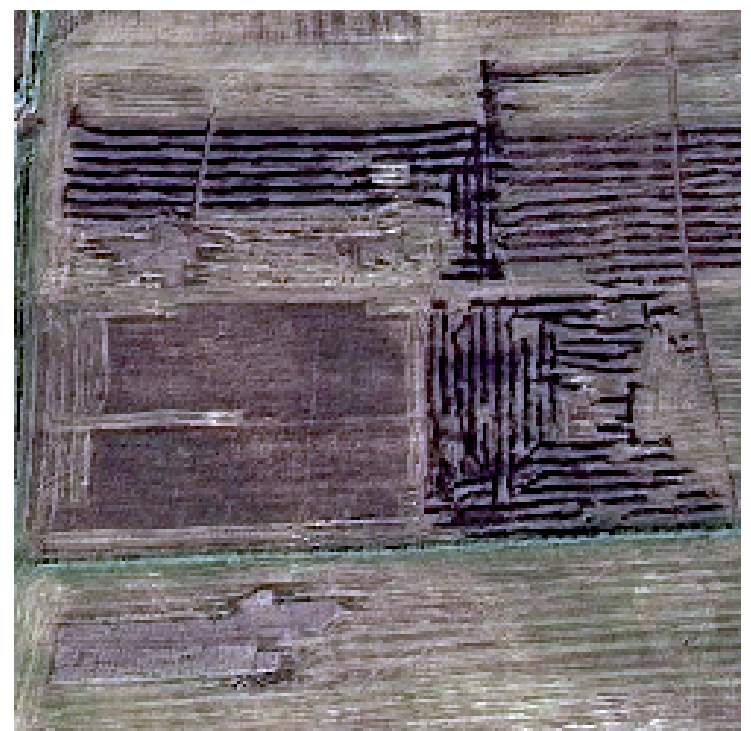

RGB

Figure 10. Orthophoto for Starogard district, September 2010. Field work carried out on the ground during the water saturation of the soil profile 


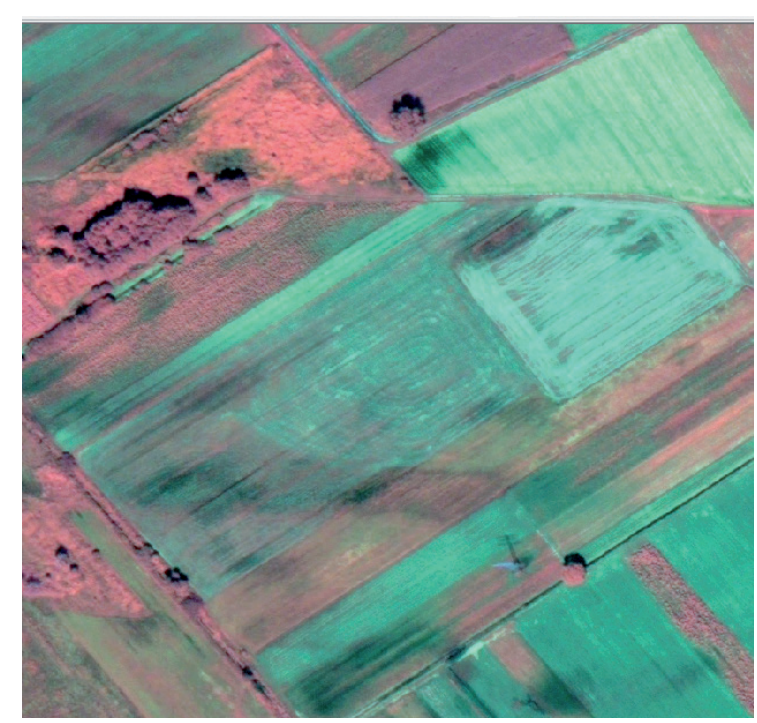

Infrared composition

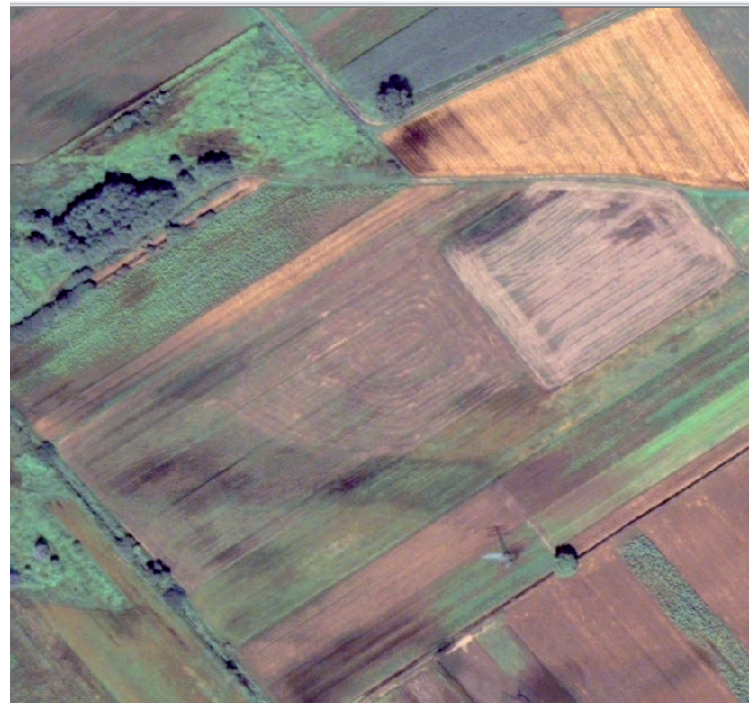

Pseudo-natural composition

Figure 11. Satellite orthoimage for Powsin district, August 2011. Tracks of mowing without entering waterlogged area.

\section{Conclusions}

Although the research covered only some of the GAECs' requirements it can be stated high potential for VHR images for monitoring of cross-compliance and enhancing the overall control process. Both kind of aerial and satellite orthophoto can be consider as equivalent materials. In conclusions the main advantages and disadvantages are presented.

\section{Advantages}

Features or phenomenon spread over a large area or pointwise but in depth of crops are detectable easier in image than during field inspection. For instance erosion effect or plants growing in ridges along the slope is easier to define from a broader perspective. Also wherever access or visibility on the ground is limited due to the morphology complexity, road network, etc., orthophotomaps provide better angle of view. Therefore RS data, especially satellite images are suitable tools for a complete and continuous territorial monitoring and risk analysis cover large area. The phenomenon like burning or soil saturation if occurred are easy to detect whether on satellite or aerial orthophotos.

\section{Disadvantages}

Trees canopy, high constructions and their shadows are obviously constrain photo-interpretation and may mislead observer (especially in case of water courses or ponds borders). Also check of weed on permanent crops or mowing in particular time can be difficult using photo-interpretation techniques only. The ratio benefit/cost for managing the entire control on national level should be calculated and check against the efficiency of field control.

\section{Acknowledgements}

We are grateful to ARMA, Reference Databases Department Director Robert Pośnik and On-the-Spot Control Department vice-Director Ilona Łopaciuk for the cooperation and data providing.

\section{References}

Angileri V., 2011, The use of Remote Sensing to control GAEC, [in:] GAEC workshops materials, Vienna 3-5.10.2011 http://mars.jrc.ec.europa.eu/mars/NewsEvents/GAEC-workshop-2011/

Angileri V., Kay S., Loudjani P., Skornicki H. \& Van-Oost I., 2008, Implementation of the Farm Advisory System in Poland external JRC report Commission Regulation (EC) No 1122/2009 of 30.11.2009 laying down detailed rules for the implementation of Council Regulation (EC) No 73/2009 as regards cross-compliance, modulation and the integrated administration and control system, under the direct support schemes, Official Journal of the European Union. 2.12.2009, L 316/65. 
Council Regulation (EC) No 73/2009 of 19.01.2009 establishing common rules for direct support schemes for farmers under the common agricultural policy and establishing certain support schemes for farmers.

Csonka B., Kristóf D., Lipták K., Kocsis A. \& Kovács I., 2011, Introduction of water protection buffer strips as a GAEC measure in Hungary, using GIS and remote sensing support, [in:] GAEC workshops materials, Vienna 3-5.10.2011 http://mars.jrc.ec.europa.eu/mars/ News-Events/GAEC-workshop-2011/

Dokumentacja przyrodnicza dla pakietów przyrodniczych w ramach programu rolno środowiskowego 2007-2013 [Documentation Of Natural Habitat For Packages Under Environmental Program 2007-2013], http://www. arimr.gov.pl.

European Commission JRC, 2011a, Common Technical Specifications for the 2011 campaign of Remote Sensing Control of area based subsidies. http://mars.jrc. ec.europa.eu/Bulletins-Publications.

European Commission JRC, 2011b, VHR Image Acquisition Specifications for the CAP Controls (CwRS and LPIS QA). http://mars.jrc.ec.europa.eu/mars/Bulletins-Publications/VHR-Specifications-2012.

Korycińska A. 2010, Przyszłość cross-compliance w świetle dyskusji o systemie płatności bezpośrednich po 2013 [The future of cross-compliance in the light of the discussions about the system of direct payments after 2013], [in:] Workshop materials of Agricultural Advisory Centre, Radom.

Lafforgue C. \& Petitjean A., 2011, Good Agricultural and Environmental Condition in FRANCE, [in:] GAEC workshops materials, Vienna 3-5.10.2011 http://mars. jrc.ec.europa.eu/mars/News-Events/GAEC-workshop-2011/

Pyka K. \& Świerczek P., 2005, Ortofoto dla odważnych, Doświadczenia Małopolskiej Grupy Geodezyjno-Projektowej z wykorzystania zdjęć lotniczych i satelitarnych do kontroli rolniczych dopłat obszarowych [Orthophoto for the brave. experience malopolska survey and design group on the use of aerial and satellite imagery for monitoring agricultural area payments], Geodeta 7 (122).

Rossi L., Serafini C., Biscontini D., Tosi P., Ciabocco G. \& Tiberi M., 2011, Defining buffer strips in Italy: results of preliminary tests, [in:] GAEC workshops materials, Vienna 3-5.10.2011 http://mars.jrc.ec.europa.eu/mars/ News-Events/GAEC-workshop-2011/

Rozporządzenie Ministra Rolnictwa i Rozwoju Wsi zmieniające rozporządzenie $\mathrm{w}$ sprawie minimalnych norm w tym wykaz obszarów zagrożonych erozją wodną, [Regulation of the minister of agriculture and rural development amending the regulation on minimum standards and the list of areas at risk of water erosion], Dziennik Ustaw z 13.03.2009 poz. 327.

Tosi P., 2011, RS tools to monitor the retention of landscape features, [in:] GAEC workshops materials, Vienna 3-5.10.2011 http://mars.jrc.ec.europa.eu/mars/ News-Events/GAEC-workshop-2011/

Wężyk P., Szostak M. \& Tompalski P., 2009, Porównanie dokładności metody "Foto" z automatyczną analizą danych lotniczego skaningu laserowego dla celów kontroli dopłat bezpośrednich [Comparison of the accuracy of the PHOTO check method with automatic analysis based on ALS data for direct control of subsidy payment], Archiwum Fotogrametrii, Kartografii i Teledetekcji 20: 445-456.

WikiCAP http://marswiki.jrc.ec.europa.eu/wikicap/index. php.

Zasada wzajemnej zgodności. Minimalne normy, obszar A i B obowiązujący od 2011 [Cross-complience. Minimum standards, area A and B in force since 2011]. Brochure for farmers, materials of the Ministry of Agriculture and Rural Development, http://www.arimr.gov.pl/ fileadmin/pliki/kontrole/broszura_internetowa_2011. pdf.

Zauner A., 2011, Good agricultural and environmental condition in Austria, [in:] GAEC workshops materials, Vienna 3-5.10.2011 http://mars.jrc.ec.europa.eu/mars/ News-Events/GAEC-workshop-2011/ 
